\title{
Science and Technology for Sustainable Development in Indian Scenario
}

\author{
V. JaiGanesh and P. K. Nagarajan
}

\begin{abstract}
Exponential Growth of Technology in India has played a significant role in all round development and growth of economy in our country. Sustainable development is an emerging area, because it addresses the socio economic development of every human being. India has opted for a judicious mix of indigenous and imported technology. Purchase of technology is commonly called "Technology transfer" and it is generally covered by a technology transfer agreement. This work focuses on the key areas of sustainable developments and scientific contributions towards it. This write-up almost identifies the critical issues or problems associated with sustainable development. Identifying the problems and giving the necessary recommendations for solving the problems encountered. The development of any country is almost depends on the advancement in developing the technology in different fields. The revolution takes place between eighteenth and nineteenth centuries makes a world to think differently in the science and technology steam engines, textile, printing etc. Countries that take part across this industrial revolution are developed much more than other countries because the machine occupies the work more from men. Further advancements in twentieth century in space, aircraft, computers, biotech and information technology are boost the developed nations much advanced. The new technology with young minds creates a synergy both in knowledge and resource utilization.
\end{abstract}

Index Terms-Sustainable development, science and technology, government of India, nuclear technology, biotechnology, immediate technology.

\section{INTRODUCTION}

'Technology transfer' means the use of knowledge and when we talk about transfer of the technology, we really mean the transfer of knowledge by way of an agreement between the states or companies. 'Transfer' does not mean the movement or delivery; transfer can only happen if technology is used. So, it is application of technology and considered as process by which technology developed for one purpose is used either in different applications or by a new user.

\section{A. Elements of Technology}

Technology generally would comprise the following elements:

Process Know how

Design Know how

Engineering know how

Manuscript received January 7, 2013; revised March 7, 2013.

The authors are with Department of Mechanical Engineering, S.A. Engineering College, Veerarahavapuram, Tiruverkadu Post, Poonamallee-Avadi Road, Chennai - 600 077(e-mail: drjai@saec.ac.in, pknagarajan@saec.ac.in).
Manufacturing know how

Application Know how

Management know how

The technology what we have utilizing today supports the necessity for human comfortable life zone. The field in improvements is basically takes place on Medicine, Energy, Agriculture and Resource Management which makes greater impact on the society. Sound decision making and economic planning are necessary for nation's sustainable development. The global look must address the scientists and entrepreneurs from all over the nations for towards the improvement of sustainability. The report framed by Brundtland commission defines the sustainable development as "the development that meets the needs of the present, without compromising the ability for the future generation to meet their own needs".

\section{NuClEAR TECHNOLOGY}

Technology can either be developed through own research and development or it can be purchased through indigenous or imported sources. Radiation techniques are used in agriculture for producing high yields with better crops. The technique called Nuclear Sterilization (NS) is used to eradicate the tests flies and have also been used to control the harmful effects of pesticides for human being. Radiation techniques are also has an application to preserve food by eliminating bacteria and pathogens that can cause disease.

It also prevents the harmful effects of chemicals that are presently being used in fumigation of food. For effective sustainable agriculture and to get maximum benefits such as water and fertilizer the nuclear techniques are used to optimize the intake of water and fertilizer-uptake. This technique is also used for mapping of micronutrients. Nuclear techniques are used in mutation-breeding have resulted in producing improved varieties of cotton, wheat, chickpeas, mungbeans and rice. Fig. 1 shows the Nuclear power production in India.

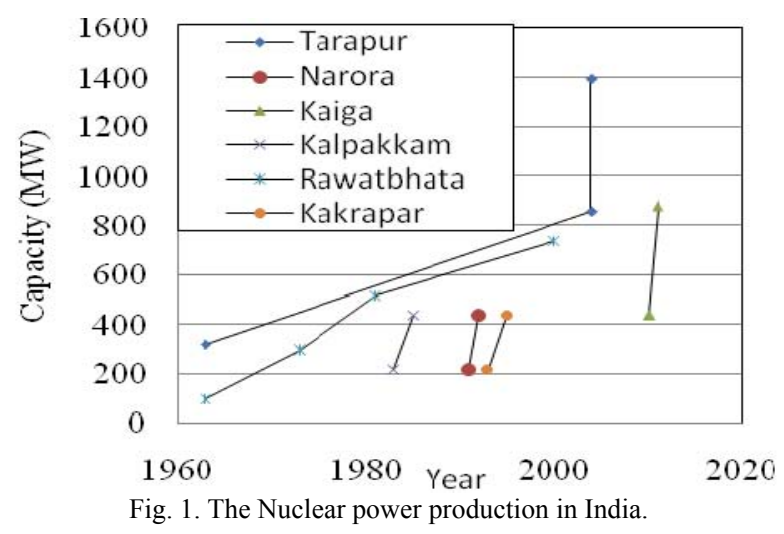




\section{Human HeAlth AND MEdicine}

Human health is one of the key factor that must be addressed today's sustainable development. Nuclear techniques are used to diagnose and treatment of diseases. Nowadays it is one of the powerful diagnostic techniques. Radioscopic techniques are used in the area of health science in treatment of cancer as the cases of cancer are increasing rapidly all over the world. Gamma irradiation facility is used for sterilizing the medical equipment.

\section{WATER RESOURCES}

Clean water is the need of the hour all over the world and an increasing awareness in the world that fresh water is a precious and limited resource. Ground water is shrinking due to over-exploitation and being lost due to degradation of water-quality from pollution cause by humans. The standard of living and over population are the main demand for produce clean water. Global warming is also one of the additional inputs for demand for water. Sustainable improvement in freshwater resources requires appropriate technologies like radioactive isotopes and radioactive tracers.

\section{INDUSTRY}

Non-destructive Testing (NDT) is a quality control technique and quality assurance is the key requirement in modern industry. Services using nuclear control techniques are being used in a number of industries, including oil sectors, fertilizers and chemical plants. The services are also extendable to hydroelectric and thermal power plants. The quality assurance laboratories using nuclear analytical techniques are essential requirements in industries.

\section{INFORMATION TECHNOLOGY}

Information technology plays a vital role in today's societal importance, knowledge and intelligence empowers both people and machines with information. The utilization of machines, men, method and money contributes effective sustainable development. Empowered people are playing the role as citizens to support environmentally sustainable society similarly empowered machines have the knowledge to minimize energy and material use, wastes and pollutants. Information technology improves the facilities faster, cheaper and equitable and resource efficient access to information, improving learning environment for people. Internet tools facilitate people to access the information globally and processing, storing, transmission made easier in electronic form. Fig. 2 shows the Internet user in India is raised gradually.

\section{BioteChNOLOGY}

The fields of biotechnology are a multidisciplinary nature and contain many scientific approaches on it. It began in 70's with genetics and DNA technology [1]. The genetic engineering is covers almost all areas including, Agriculture, Environment, Industry and Human Health. The application of biotechnology knowledge gives human kind the ability to alter the structure of life itself. The modern concepts like Cloning, Genetic Algorithm, Ant colony optimization, Swarm Optimization and Artificial Intelligence techniques are and new heuristics are developed on nature inspired plants and animals [2], [3]. Biotechnology techniques are boom for the human community and it depends on how it is used and controlled. The genetic engineering has got the industrial revolution when it was introduced and some the areas in which it perform well such as produce new and safer vaccines, treating genetic diseases, increase crop-yields, decrease production costs, improve food nutritional values, develop biodegradable plastics and decrease water and air pollution [4].

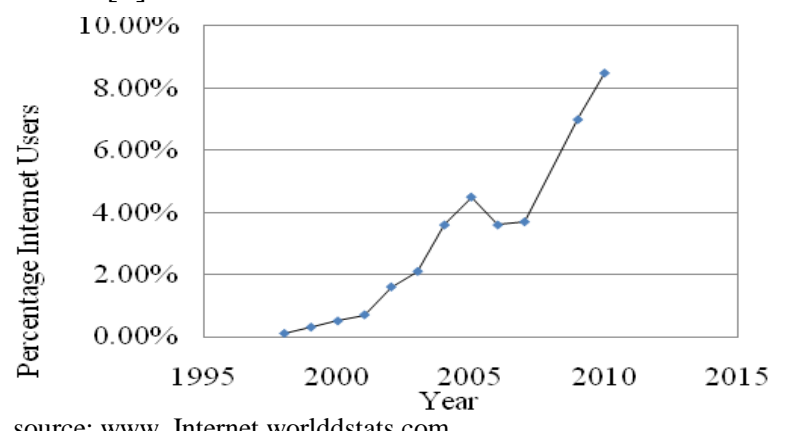

Fig. 2. Internet user growth in India

\section{Sustainability In THE AREA OF FinANCE}

Access to sound technologies is essential for sustainable development. The investment decisions and transfer of technology are key vital part during trade. The imported technology has to be compromised, against the bargaining position [5]. The vendor selection and selecting areas will safe guard the environment and enabling them to upgrade the human resources. The capacity building through technology acquisition, skill development and evolution of local policies and support for technology transfer process. The problems like market intervention of intermediation and matching technology with suitable applications, brokering partnerships, negotiations and devising financial packages. Replication or indirect effects must not affect the results and creation of such funds from includes: Project designs; through demonstrations, Resource mobilization, Improved regulatory frameworks and standards, Augmenting technical capacity, Devising new institutional models, and Encouraging stakeholder dialogues.

\section{Sustainable Human Resource Management}

Human Resource Development is the important area for sustainable development of managing the human resources. Something from our own experience and some from experiences of others it's a way of transferring the knowledge and skill to offspring through grooming [6]. Everyone expects their skill and knowledge has to be transferred to their offspring's and to become more respectable members of their societies. Some of the critical factors for sustainable HRD are the population explosion, the rising expectations and the ongoing knowledge revolution. 


\section{Sustainability on ImMEdiate TeChNOlOGY}

The change in technology should not confuse with the technical changes that takes place nowadays. Change is now necessitated by national and global environment concerns were that the need to the poor must be addressed. "...the major obstacle to the development of the rural poor is the so-called educated man."-- Bunker Roy, Indian Express, 1983 [7], [8]. As social, economic and political problems increase in our technology-revolve world, it is important to inquire where we have gone wrong, and to seek alternative paths to sustainable development. Government of India issues from time to time lists of Industries "where foreign investment may be permitted". [9], [10]. No doubt, a broad technology base has been created in the country, yet a need to update the production technology may arise due to constant technological advancements in developed countries .Government of India (foreign investment Promotion Board) may consider import of technology

\section{CONCLUSION}

The need of the hour is to identify the key areas in the planning activity for sustainable development. Identify the present scenario of science and technology activities of developed countries. The isolated areas of particular research interest must be addressed for which the improvements could combine together and supports the lack of expertise for the individuals. The infrastructure developments on sustainability developments must be addressed with high sophisticated channels. Most of the countries have agriculture -based economies with the usage of sustainable technology the crop yields can be raised [11]. So far the development on sustainable technology lacks behind in the areas of human resource development due to resistance to change, lack of awareness, and adoption of technologies using rapid technological development in all private sectors [12].

\section{REFERENCES}

[1] K. A. Malik, A. Nasim, and A. M. Khalid, "Biotechnology for Sustainable Development," National Institute for Biotechnology and Genetic Engineering (NIBGE), Faisalabad, Pakistan, pp. 21, 1995.

[2] M. Shah and M. Strong, "Food in the 21st Century: From science to sustainable agriculture," CGIAR System, Review Secretariat, The World Bank 1818 H Street, NW, Washington D.C. 20433 USA, pp. 1-72, July 1999 .

[3] J. J. Doyle and G. J. Persley (Eds), "Enabling the Safe Use of Biotechnology Principles and Practice," Environmentally Sustainable
Development Studies and Monographs Series No. 10. The World Bank 1818 H Street, NW, Washington D.C. 20433, USA, pp. 29-42, July, 1999.

[4] J. Komen, C. Falconi, and H. Hernandez (Eds), "Turning Priorities into Feasible Programs," in Proceedings of a Policy Seminar on agricultural Biotechnology for Latin America, Peru, pp. 6 - 10, Oct. 1996.

[5] A. Djoghlaf, "The global environment facility: Financing technology transfer for climate change," Tech Monitor, pp. 14, Jul-Aug. 2000.

[6] Chambers and Robert, Rural Development: Putting the Last First, Longman, London, pp. 1-246, 1983.

[7] E. F. Schumacher, Small is Beautiful, Blond and Briggs, London, pp. 109-110, 1973.

[8] A. K. N. Reddy, "Alternative technologies: A viewpoint from India," Social Studies of Science, vol. 5, no 3, pp. 331-342, 1975.

[9] K. Ghulam, Technology Acquisition in Pakistan - Story of a Failed Privileged Class and a Successful Working Class, City Press, Karachi, pp. 446, 1998.

[10] S. Najma "A cruel betrayal and a crude awakening - an interview of Ghulam Kibria," The News, pp. 36-58, May, 2001.

[11] S. Ismail and G. J. Persley, "Promethean science: Agricultural biotechnology, the environment and the poor," Consultative Group on International Agricultural Research, Washington, D.C., pp. 1-36, 2000.

[12] Comsats, Commission on Science and Technology for Sustainable Development in the South," vol. 2, pp. 1-88, Sep. 2003.

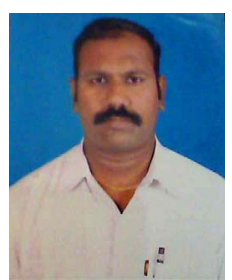

V. JaiGanesh was born in Tiruvallur on $11^{\text {th }}$ May 1977. V. JaiGanesh completed his Doctoral Degree in Mechanical Engineering at Anna University, Chennai and Masters in Industrial Engineering at National Institute of Technology, Tirchy and Bachelors degree in Production Engineering at Madras University, Chennai in the year 1999.

He is presently Professor and Research \& Development Head at S.A Engineering College. He was previously worked with Velammal Engineering College and St. Peters Engineering College as Associate Professor and other Engineering institutions more than a decade. He published 25 Papers on International and National Conferences and Seminars. His current research includes Waste Water Management; Sustainable Technology and Modern Welding processes.

Dr. Jaiganesh Venu is member of ISTE, IEI and also a Certified Charted Engineer. He was a recipient of Research Promotion Scheme (RPS) Award for the project title "Development of Eco Friendly High Strength FSW" for the year 2011-2012 by AICTE, New Delhi, India.

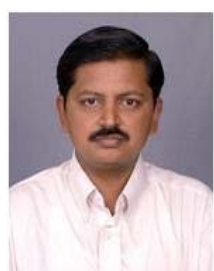

P. K. Nagarajan was born in Madurai on $4^{\text {th }}$ June 1977.He completed his Doctoral Degree in Mechanical Engineering at National Institute of Technology, Trichy and Masters in Thermal Engineering in 2000 and Bachelors degree in Mechanical Engineering at Madurai Kamaraj University in 1998.

$\mathrm{He}$ is Presently Professor in Mechanical Engineeri-

ng Department at S. A Engineering College. He previously worked with VIT University and RMK College of Engineering and Technology as Associate Professor and Professor\& Head respectively. He Published 6 international Journal papers and 10 international and National conference papers. His current research includes Nanofluids, Microchannels and Solar thermal applications.

Dr. P. K. Nagarajan is a life member in IEI. 